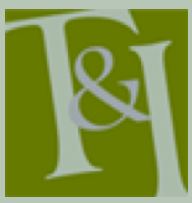

The International Journal for Translation \& In erpreting Research trans-int.org

\section{Translating technical terms into Arabic: Microsoft Terminology Collection (English- Arabic) as an example}

\author{
Sameh Saad Hassan
}

Suez Canal University, Egypt

sameh_eldamarani@art.suez.edu.eg

DOI: 10.12807/ti.109202.2017.a05

\begin{abstract}
The main aim of this paper is to explore the techniques used in translating English technical terms into Arabic in the Microsoft Terminology Collection (MTC) (English-Arabic) as an example of comprehensive multilingual resources of technical terminology on the Web. MTC is a wellknown online IT-glossary available on the Microsoft Language Portal in over ninety languages. It provides users with the opportunity to perform quick searches between different languages and to download files that integrate with Microsoft products and computer-assisted translation (CAT) tools. Some examples of MTC terms in Arabic are examined by the researcher to identify the kinds of translation strategies that MTC follows in order to translate technical terms into Arabic as well as the appropriateness of these strategies to their translation situations through comparison of different translations for the same SL term. The analysis of selected examples from MTC shows that in the Arabic translations of technical terms, MTC uses translation, Arabicisation, and Arabic-expanding techniques inconsistently, either in providing more than one translation for a standard technical term within the same translation situation or in using different translation strategies for similar technical terms in similar translation situations. Results show that it is more appropriate to use translation and/or Arabic-expanding techniques (mainly derivation and compounding) with technical terms derived from common linguistic roots in the source language (SL) to preserve the integrity and authenticity of Arabic as a target language (TL) at a time of a marked increase in the number of SL technical terms, while methods of Arabicisation should only be used with SL proper nouns or any word derived from them to solve problems of nonequivalence at word level between Arabic and English.
\end{abstract}

Keywords: technical translation, Arabicisation, Arabic-expanding techniques, Microsoft Terminology Collection (MTC)

\section{Introduction}

An examination of the literature on technical translation reveals two major fallacies about this form of translation. One fallacy about technical translation has to do with the definition of the term itself. Defined by Wright \& Wright (1993), "[t]echnical translation encompasses the translation of special language texts, i.e., texts written using Languages for Special Purposes (LSP).

Translation \& Interpreting Vol 9 No 2 (2017) 
As such, technical translation (and "technical terminology" as well) includes not only the translation of texts in engineering or medicine, but also such disciplines as economics, psychology and law" (p. 1). Similar to Wright \& Wright's definition of technical translation, Ghazala (1995) defines technical translation as, "[t]he translation of scientific and technical terms of all kinds: medical, physical, chemical, mathematical, mechanical, technological, biological, agricultural, computer and other terms of the various branches of science" (p. 156). According to Byrne (2006), such definitions make no distinction between specialised and technical translation because "[i]n reality, 'technical' means precisely that, something to do with technology and technological texts (...) Simply because a field or subject area has unique or specialised terminology does not make it technical" (p. 3). In this sense, Schubert (2010) points out that "[i]n this term, the word 'technical' refers to the content of the documents, not to the tools used" (p. 350). The problem lies, as Schubert maintains, in the semantic ambiguity of the English adjective technical, "[t]he term can relate to content either from technology and engineering or from any specialized domain" (p. 350). Thus, in the broader sense, technical translation is synonymous to specialised translation. In the narrower sense, "technical translation is one part of specialised translation" (Newmark, 1988, p. 151).

Another fallacy about technical translation has to do with the discussion of scientific and technical translation as one and the same thing. Despite the obvious connection between the two, Newmark (1988) notes, "[i]n science, the language is concept-centred; in technology, it is object-centred" (p. 155). Likewise, Byrne (2006) argues that, "[s]cientific translation relates to pure science in all of its theoretical, esoteric and cerebral glory while technical translation relates to how scientific knowledge is actually put to practical use" (p. 8). It is true that scientific and technical translation differ in terms of subject matter, language and purpose, as Newmark and Byrne maintain, yet, it seems that both types are very much alike in terms of the techniques of translation involved. That is perhaps why Olohan (2015) uses the expression scientific and technical, not as a reference to the same type of translation, but as an indication that "they share some features, challenges or approaches" ( $p$. 7) and that any discussion of technical translation can equally hold for scientific translation.

In this article, the term "technical translation" refers to the translation of materials dealing with technological subject areas and using the specialised terminology of scientific and technological information. The main aim of the article is to explore the techniques used in translating English computer terms into Arabic in the Microsoft Terminology Collection (MTC) (English-Arabic). MTC is a well-known online IT-glossary that is available on the Microsoft Language Portal in over ninety languages. Technical terms in MTC include all categories of terminology used in the field of computer and technology: Internet (web, e-mail, attachment, cookie, etc.), hardware (screen, mouse, printer, floppy disk, etc.), software (freeware, antivirus, install, data, etc.), measurement units (bit, byte, megabyte, gigabyte, etc.) and tech acronyms ( $A D S L, B I O S, C P U, U S B$, etc.). The main problem in the translation of technical terminology into Arabic in MTC as an example of comprehensive multilingual resources of technical terminology lies in using translation, Arabicisation, and Arabic-expanding techniques inconsistently either within the same translation situation (in providing more than one translation for a standard technical term) or between similar translation situations (in using 
different translation strategies for similar technical terms). Due to the fact that MTC is a free product by the world's leading producer of computer software that can integrate with Microsoft products and computer-assisted translation (CAT) tools, it is likely to be used by a large number of users to develop localized versions of applications that integrate with Microsoft products. Therefore, MTC (English-Arabic), used across Microsoft products and in MTC-based free online translation services (e.g. Bing Translator) will inevitably influence the translation of texts and webpages as well as the translation environment in Windows operating systems and applications designed to the Arabic-speaking market.

For the purpose of the current study, technical terms from MTC will be classified into three categories: translated technical terms (TTTs), expanded technical terms (EXTTs) and Arabicised technical terms (ATTs). The first category, i.e. TTTs, involves nominal and verbal TL technical terms. The second category, i.e. EXTTs, comprises mechanisms of word formation. The two main word-formation processes to be examined are derivation and compounding. According to Dirven and Verspoor (2004), "[t]he two main word-formation processes are compounding and derivation. Compounding is a case of conceptual blending (...) At the linguistic level, two free morphemes are combined to form a compound (...) In contrast to a compound, a derivation consists of a free morpheme and a bound morpheme" (p. 71). Dirven and Verspoor maintain that "[o]ther word formation processes are less productive, i.e. they apply to smaller sets of words" (p. 71). More restricted processes of word formation to be examined in this study include blending in which "parts of two familiar words are yoked together (usually the first part of one word and the second part of the other) to produce a word which combines the meanings and sound of the old ones" (Stockwell \& Minkova, 2001, p. 6) and acronyms and initialisms in which "a typical acronym takes the first sound from each of several words and makes a new word from those initial sounds. If the resulting word is pronounced like any other word it is a true acronym (...) If the letters which make up the acronym are individually pronounced ... such acronyms are called initialisms" (Stockwell \& Minkova, 2001, pp. 7-8). The last category, i.e. ATTs, involves phonological and morphological changes that occur to SL terms. All TTTs and EXTTs are semantic loans that existed in the TL before they acquired their technical meanings from the SL, and all ATTs are lexical loans adopted from the SL and incorporated into Arabic without translation.

\section{Theoretical background}

For decades, a number of studies in the field of technical translation tried to explore methods of translating technical and scientific terminology into Arabic. In many of these studies, however, there is an overlap between concepts of translation, Arabization, Arabicisation, and Arabic-expanding techniques (linguistically known as word-formation processes). For example, Benabdi (1980) defines Arabicisation as "the deliberate effort to spread the use of classical Arabic" (p. iii). Numan (1981) views Arabicisation as "a means of liberation and modernization to achieve the goal of national, cultural, and political independence at Arab level" (p. 14). Likewise, AlSayadi (1982) refers to two different meanings of Arabicisation, one in the east Arab countries that "refers to lexical expansion which involves the 
rendering or coinage of new words", and another in the north African Arab countries which refers to the use of Arabic instead of the foreign language in all the domains of life (as cited in Hartford \& Obeng, 2002, p. 153). However, Baker (1987) notes that:

Arabization involves the rendering of foreign terms into Arabic in its original linguistic form, after introducing minor phonetic and/or morphological changes where necessary. This method has received much opposition from language purists, who fear that the assimilation of foreign terms may change the identity of Arabic and, if applied to excess, would even result in some form of a hybrid language. (p. 187)

Therefore, Al-Abed Al-Haq (1998) argues that Arabicisation and Arabization denote different meanings because the former "is derived morphologically from Arabic, that is, the language, and therefore denotes more adequately the idea of Arabic language planning", whereas the latter "indicates a reference to Arabs, i.e., the people and culture" (p. 55).

Ghazala (1995) uses the term "Arabization" or "Arabicization" as a synonym for technical translation, "Arabization (or Arabicization, by analogy to Anglicization, Germanization, etc.) is the translation of technical terms into Arabic" (p. 156) and introduces the following as methods of Arabicisation: transcription, naturalisation, translation, and coinage (revival, derivation and neologisms). However, this classification ignores the fact that Arabicisation and translation are two different processes. Whereas translation works on "substituting words from one language to another" (ترجم الكلام: نقله من لغة إلى ) (أخرى (al-Mu'jam al-Wasìt, 2004, p. 83), ta 'rīb (Arabicisation) works on "adapting foreign words to the phonetic or structural pattern of Arabic" (التعريب: صبغ الكلمة بصبغة عربية عند نقلها بلفظها الأجنبي إلى اللغة العربية) Mu jam al-Wasìt, 2004, p. 591). Overlapping methods of Arabicisation and translation also contradict Newmark's classification (1988), in which transference and naturalisation (i.e. methods of Arabicisation) are included as "other translation procedures" (p. 81) and revival and derivation are methods of creating neologisms (p. 150). Moreover, there is an overlap in the examples of technical terms that Ghazala gives for revival, derivation and neologisms. For example, the word car, translated as (سيّارة), is given as an example of revivals (old words with new senses) even though the same word can also be given as an example of an EXTT which involves derivation from the Arabic root sayr (سير with the morphological pattern of the Arabic ism al-'alah (noun of instrument) (fa'ālah فقالة) just like bicycle (درّاجة) or washingmachine (غسّالة). Similarly, the word computer (حاسب آلي/حاسوب) is given as an example of neologisms, although it is also an example of an EXTT derived from the Arabic root hasaba (حسب).

Therefore, a distinction is made in this article between methods of translation, Arabicisation and Arabic expansion so that translators can choose among them in their translations of technical terms. Whereas the main concern of translation, as a process, is decoding the SL text and finding equivalents in the TL, the main concern of Arabicisation (transliteration or naturalisation) and Arabic-expanding techniques (such as derivation, compounding, blending, etc.) is to solve problems of non-equivalence at word level between Arabic as a TL and other source languages. For the purpose of this study, the term Arabicisation is used as Al-Qinai (2000) defines it "Arabicization is a process whereby foreign words are incorporated into the language with phonological 
or morphological modifications so as to be congruent with Arabic phonological and morphological paradigms" (p. 1). This is an accurate definition of Arabicisation for several reasons. First, it serves to set the concept of Arabicisation apart from similar concepts such as Arabization, translation, and Arabic-expanding techniques. Second, it indicates that Arabicised terms involve al-dakhīl (the transliterated) and al-mo'rrab (the naturalised). Finally, this definition agrees with the classical concept of $t a$ ' $r \bar{\imath} b$

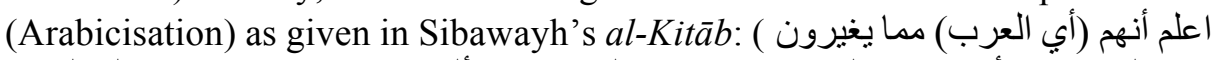
(من الحروف الأعجمية ما ليس من حروفهم البتة، فربما ألحقوه بيناء كلامهم وربما لم يلحقوه 304 translated by Stetkevych (1970) as "[t]he Arabs change those foreign words that are absolutely incongruous with their own, sometimes assimilating them into the structure of their words, and sometimes not" (p. 59).

In their study on Arabicisation and Arabic-expanding techniques, Al-Asal and Smadi (2012) recommend Arabization or "using Arabic in our education as a medium of instruction and a tool of expression" (p. 32). Yet, the real problem in English-Arabic technical translation lies not in the choice between Arabic and the foreign language but in the choice between the Arabicised word and the Arabic word. According to Chejne (1969), there are three different attitudes towards Arabicisation: "One school is generally opposed to Arabization on the grounds that it will lead to an overflow of foreign words that ultimately do violence to the language", another school "favors the indiscriminate use of foreign words in the original form" and finally, a third school "insists that foreign words can be accepted only as a last resort after every effort has been made to find their equivalents in Arabic" (p. 179). The same controversy is highlighted by Versteegh (2014):

In the classical period, this procedure of Arabicisation ( $t a{ }^{\prime} r \bar{l} b$ ) was very successful, the number of unadapted words remaining minimal. In the modern world, the academies adopted a restrictive policy, allowing loans only in scientific terminology. . . The real controversy arose around the question as to whether or not foreign words could be used as productive roots for new derivations. In classical Arabic, once a foreign word had been admitted and adapted, it behaved like any other Arabic word, but in the modern world the academies tried to restrict new derivations to scientific terminology. (p. 229)

At a time of a marked increase in the number of SL technical terms, the use of foreign words as productive roots for new derivations to scientific terminology in Arabic becomes even more controversial. Also, the question whether the users' opinion, regarding certain translations they find appropriate for the daily use, should be considered in technical translation is based on the distinction between technical slang and formal terminology. For example, some technical terms, though not accepted as Standard Arabic, are currently used in their Arabicised forms among specialists and non-specialists alike: e.g. hard (هارد), case (هيسة), headphones (هيدفون), format (يفرمت), delete (يدلَّ), save (يسيّف), and "to Facebook (يفسبك)" (Abu Hatab \& Lahlali, 2014, p. 90). In this regard, Bernstein (1995) argues:

Those in specialized fields have a need to communicate with one another in precise terms and with an economy of expression. A single word will often convey to a colleague what would require a sentence, a paragraph, or perhaps an even longer description to convey to a layman (...) A final caution may be of value in a discussion of inside talk. In writing intended for general reading, 
the use, whether by a specialist or by a layman, of jargon terms that are not commonly understood smacks of pedantry. If the writer believes that it is imperative to use such a term, he should at least explain it when it is introduced. It must never be forgotten that the function of writing is communication. (p. 237)

Bernstein's warning draws attention to the necessity of using the SL technical term within its proper sphere. If this is the case for the SL technical term, then the TL technical term should also be used within its proper sphere depending on its level of formality.

\section{Research questions and method}

Through the discussion of methods of technical translation in MTC, this article attempts to answer the following questions: What kinds of translation strategies does MTC follow in order to translate technical terms into Arabic? How can SL and TL technical terms be classified in terms of phonological, morphological and semantic changes? When should translation, Arabicisation, or Arabic-expanding techniques be used in English-Arabic technical translation? To answer these questions, the selected data is analysed comparing translations of the SL terms in MTC with translations of the same terms in Mu'jam Muștalahāat al- Hasibāt (Dictionary of Computer Terms) مَجمعُ اللغةِ العربيةِ (2012) by the Academy of the Arabic Language in Cairo (بالقاهرة), to explore the appropriateness of the methods of translation, Arabicisation, or Arabic-expanding techniques that were used in MTC to provide equivalents for the technical terms. First, examples of the SL technical terms representing different types of computer terminology (Internet, hardware, software, measurement units and tech acronyms) are selected from MTC. Second, the technical terms are classified into three groups (translated technical terms, expanded technical terms, and Arabicised technical terms) according to the changes that occur to the given TL equivalents at different levels of language (phonological, morphological, lexical, semantic, etc.). Third, the SL terms are looked up in Merriam-Webster's Online Dictionary to check out their meanings in General English (GE) and/or English for Specific Purposes (ESP), word class, popularity of the term and date of the first use. Fourth, the given TL equivalents are looked up in al-Mu 'jam al-Wasit (alWasit Arabic-Arabic Dictionary) (2004) to check their meanings and whether Arabicised terms have found their way into Modern Standard Arabic (MSA). Finally, some observations are given by the researcher about the types of TL technical terms, and the possible translation method(s) for each type.

\section{Data collection}

MTC is a set of standard technology terms in many languages available at the Microsoft Language Portal. The Search Terminology box in (https://www. microsoft.com/Language/en-US/Search.aspx) allows users to perform quick searches in different languages. MTC (English-Arabic) can be saved in TBX file format (Microsoft Term Collection.tbx) from (https://www.microsoft.com/ Language/en-S/Terminology.aspx). A Microsoft terminology file contains the following data: concept ID, definition, source term, source language identifier, target term, and target language identifier. It can integrate with Microsoft 
products and computer-assisted translation (CAT) tools. According to Olohan (2015), "[t]he TBX (TermBase eXchange) file format is an international standard for terminology data, and all terminology-management software should allow you to import and export data in that format" (p. 43). The significance of terminology-management software for translators, Olohan (2015) maintains, lies in that:

Terminology-management software (...) is very likely to be integrated with translation-memory software. This means you can then benefit from an automatic search for your recorded terms as you encounter them in your ST during the translation process; the software will automatically display the search results, so that you do not have to decide whether to search. If you have recorded a TL term in your termbase already, this automatic retrieval makes it easy for you to copy or insert it into your translation, if you wish. If nothing is found, the software also allows you to add a new term entry quickly as you translate. This will then provide a TL term suggestion for you the next time you encounter the SL term. (p. 43)

\section{Data analysis and results}

The collected data has been classified into three categories: translated technical terms, expanded technical terms, and Arabicised technical terms. These types are classified according to the linguistic changes that occur to the technical term during the process of translation.

\subsection{Translated technical terms (TTTs)}

TTTs are TL technical terms which are based on full equivalence between the $\mathrm{SL}$ and the TL. Equivalence in this category is qualitative, i.e. the SL and TL words refer to the same thing, and quantitative, i.e. there is a single TL expression for a single SL expression. Table 1 below lists some examples of TTTs in MTC.

Fundamentally, TTTs can be classified as nominal or verbal. The SL terms in this category include terms derived from common linguistic roots such as address (عنوان), access (دول), chat (دردشة), chip (شريحة) etc. They denote any or all of a class of entities and they can be preceded by an article or other limiting modifiers (e.g. an address, my disk, etc.). They are not capitalised in the SL text unless they begin a sentence or are part of a title. In MTC, technical verbs such click (نقر), copy (نسخ), save (حفظ), download (تنزيل) etc. are translated into Arabic as mașdar (verbal noun), along with their translations as verbs, to refer to the action or activity implied in the verb when used in isolation.

A common feature of TTTs is that they are all semantic loans in the sense that an old TL term is assigned a new technical meaning. For example, the word address (عنوان) was used in the TL to refer to (ما يُستنل به على غيره) "the words and numbers that are used to describe something" (al-Mu 'jam al-Wasitt, 2004 , p. 633) before it acquired its technical meaning from the SL as "the letters, numbers, and symbols that are used to direct an e-mail message or to show the location of a site on the Internet" (Merriam-Webster's Online Dictionary, 2016). Equally, the word chat was used in the TL to mean (الدردشة: اختلاط الكلام وكثرته (لفظ مُوَلَّد)) "to babble” (al-Mu 'jam al-Wasìt, 2004, p. 279), then it acquired its technical meaning from the SL "to talk over the Internet by sending messages back and forth in a chat room" (Merriam- 
Webster's Online Dictionary, 2016). Yet, this does not necessarily mean that all SL technical terms existed, like the TL terms, before they acquired their technical meanings. For example, the words download and upload, according to Merriam-Webster's Online Dictionary, were first used in 1977 as purely technical terms in the field of computer technology. The word Word,

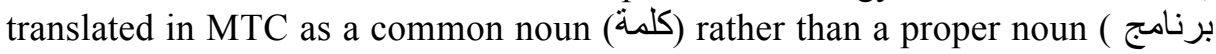
(معالجة النصوص (M), is an example of mistranslation. The word disc is translated as (قرص) (Mu'jam Muștalahāàt al-Hasibāt, 2012, p. 6) to avoid confusion with

Table 1. Translated technical terms (TTTs) in MTC

\begin{tabular}{|c|c|}
\hline SL Technical Terms & MTC Arabic \\
\hline access & وصول \\
\hline address & عنوان \\
\hline algorithm & خوارزمية/لو غاريتم \\
\hline automation & تلقائية/ آلية \\
\hline chat & دردشة / يدردش \\
\hline chip & شريحة \\
\hline click & نقر / ينقر \\
\hline coding & 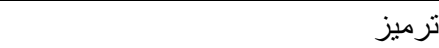 \\
\hline configuration & تكوين \\
\hline connection & اتصـال \\
\hline copy & نسخ / ينسخ \\
\hline data & بيانات \\
\hline devices & أجهزة \\
\hline digital & رقمي \\
\hline disc & قرص \\
\hline download & تتزيل / ينزل \\
\hline file & ملف \\
\hline filter & تصفية / يصفي \\
\hline input & 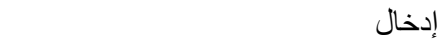 \\
\hline information & معلومات \\
\hline insert & إدراج / يدرج \\
\hline installation & تشييت \\
\hline link & وصلة \\
\hline $\log$ & سجل / يسجل \\
\hline mathematical & رياضي \\
\hline options & خيار ات \\
\hline output & إخراج \\
\hline save & حفظ / بحفظ \\
\hline screen & شاشة \\
\hline storage & تخزين \\
\hline tools & أدوات \\
\hline upload & تحميل / يحمّل \\
\hline Word & كلمة \\
\hline
\end{tabular}


cylinder, although the TL word also means ( القرص الذي تسجل فيه أصوات الغناء أو (al) (الموسيقا أو غيرهما (al-Mu jam al-Wasīt,, 2004, p. 17). Likewise, the word automatic is translated in MTC as (تلقائي/آلي) whereas Mu 'jam Muṣtalahāat alHasibāt (pp. 39-40) uses the Arabicised form (أونوماتي) and the translated form (تلقائي/آلي) concurrently for no good reason. It is more appropriate to use (حسابي) as a translation for mathematical rather than (رياضي), which is also the adjective for sport (رياضة) in Arabic. The word logarithm in MTC is given in both forms, the translated and the Arabicised. Yet, the translated form is more accurate since the SL word itself is a mangled transliteration of al-Khawārizmī, the surname of the Muslim mathematician.

\subsection{Expanded technical terms (EXTTs)}

EXTTs are TL technical terms produced from TL roots by means of wordformation processes such as derivation, compounding, blending, etc. Just like TTTs, EXTTs are semantic loans where the TL word already exists before it acquires its technical meaning from the SL. The main difference between TTTs and EXTTs is that TTTs involve semantic transfer only whereas EXTTs involve, along with semantic transfer, morphological processes that occur to the Arabic root to become a technical term. Table 2 lists some examples of EXTTs in MTC.

Table 2. Expanded technical terms (EXTTs) in MTC

\begin{tabular}{|c|c|}
\hline SL Technical Terms & MTC Arabic Translation \\
\hline accelerator & مُسَرِّع ع \\
\hline accessory & مُلْحَق \\
\hline accumulator & مُرَكَمْ \\
\hline adapter & مُحوِّل \\
\hline antivirus & مكافحة الفيروسات \\
\hline attachment & مُرفَقْ \\
\hline Biotechnology & التقنية البيولوجية \\
\hline blog & مُدوَّنَة \\
\hline browser & مُتصفَح/مُستعرِض \\
\hline$C D$ & قرص مضغوط \\
\hline cookie & ملف تعريف الارتباط \\
\hline CRT display screen & شاشة كاثودية \\
\hline CPU & وحدة المعالجة المركزية \\
\hline decryption & فلك التشفير \\
\hline desktop & سطح المكتب \\
\hline disk drive & مُحرِّك الأقر اص \\
\hline digital video disk DVD & قرص الفيديو الرقمي \\
\hline document & مُسنَتَد \\
\hline driver & برنامج تشغيل الجهاز \\
\hline electromagnetic & كهرو مغناطيسي \\
\hline e-mail & بريد إلكتروني \\
\hline emoticon & رموز المشاعر \\
\hline ENTER key & مفتاح الإدخال \\
\hline
\end{tabular}




\begin{tabular}{|c|c|}
\hline File Transfer Protocol & بروتوكول نقل الملفات \\
\hline finger & أداة البحث عن المعلومات \\
\hline firewall & جدار حماية \\
\hline forum & منتدى \\
\hline header & رأس الصفحة \\
\hline homepage & الصفحة الرئيسية \\
\hline inbox & علبة الوارد \\
\hline Internet service provider ISP & مُوفُر خدمة الإنترنت \\
\hline key & مفتاح \\
\hline laptop & كمبيوتر محمول \\
\hline local server & مُلقًّم محلي \\
\hline mainframe & حاسب مركزي \\
\hline mobile & جَوَّ ال/محمول \\
\hline monitor & جهاز العرض \\
\hline monochrome & أحادي اللون \\
\hline Paint & الرسَّام \\
\hline password & كلمة المرور \\
\hline PDA & مساعد رقمي شخصي \\
\hline plotter & رَابِيَةة \\
\hline portable devices & أجهزة محمولة \\
\hline printer & طابِعة \\
\hline processor & مُعَالِج \\
\hline sandbox & وضع الحماية \\
\hline scanner & ماسح ضوئي \\
\hline site & مَوقِعِع \\
\hline smiley & رموز المشاعر \\
\hline spam & بريد عشو ائي \\
\hline USB flash drive & مُحرِّك أقر اص محمول \\
\hline user name & اسم المُستَخدِم \\
\hline window & نافذة \\
\hline
\end{tabular}

\subsubsection{Derivation}

Derivation is one of the most important mechanisms of EXTTs in MTC. It is "the most natural way of enriching the language without altering its identity" (Baker, 1987, p. 186). All examples of derived EXTTs in MTC belong to what is known in Arabic as al-ishtiqāq al-ṣaghīr (simple derivation), where "[t]he stem is modified by prefixation, suffixation, infixation, or more than one of these processes according to well-structured models " $a w z \bar{a} n /$ formulas" (Stetkevych, 1970, p. 7). Moreover, most derived EXTTs are nouns derived from SL concrete single nouns. As noted by Stetkevych (1970), "[c]onsidering the Arabic system of word derivation as a whole, it becomes clear that the possibilities of noun derivation are much more numerous and diversified than those of verbal derivation" (p. 10). In Table 2, examples of derived EXTTs in MTC include the main types of al-mushtaqqāt (derivatives) in Arabic: ism alfà 'il (active participle) such as (حاسب) for computer, and (مُعالِج) for processor,

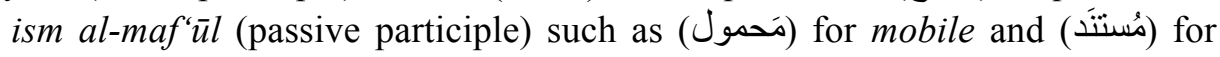


document, ism al-zarf (noun of place or time) such as (مَوقع (حتع) for site and (منتدى) for forum, ism al-'ālah (noun of instrument) such as (مَفْتاح) for key, mubālaghah (noun of exaggeration) such as (الرَسَّام) for Paint and (جَوَّال) for mobile.

The word Paint, for instance, is capitalised as an SL proper noun that refers to a Microsoft product. However, in MTC, Paint is translated as an EXTT rather than being Arabicised, which draws attention to the possibility of translating names of accessories or essential applications that are included within all versions of Microsoft Windows when used in isolation (e.g.

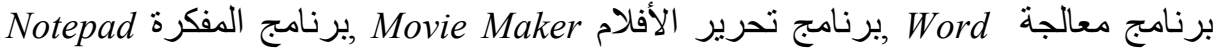
النصوص Excel برنامج العروض التقديمية excer. برنامج الجداول الحسابية etc.), unless they are referred to in the SL in comparison with similar applications by other companies (e.g. Movie Maker vs iMovie, or Paint vs Photoshop). The same strategy can be used, for instance, with a word like $i P a d$ to differentiate between the common use of the word as a small flat computer (حاسوب لوحي) and the trademark (آي باد), a tablet made by Apple. Translating window as (نافذة) is acceptable as long as it is used in the SL as a common noun to refer to "any of various rectangular boxes appearing on a computer screen that displays files or program output" (Merriam-Webster's Online Dictionary, 2016), whereas translating the proper noun Windows as (النوافذ) is evidence of an inconsistent translation policy. Inconsistency here involves using different translation strategies for similar technical terms in similar translation situations rather than using different techniques in the translation of the same term, though uniformity in technical translation (i.e. using particular TL terms for standard SL technical terms) would undoubtedly give the TL term the same meaning, depth and applications of the SL term and encourage standardisation and unification of technical terminology in the TL culture.

\subsubsection{Compounding}

Table 2 also shows that many EXTTs are translated from SL compounds. Compounding, known in Arabic as al-tarkīb, is a highly productive process as "[t]here is a limit to the number of morphemes that can be added through derivation, while in theory no such restriction exists for compounds" (Husni \& Newman, 2015, p. 41). Some compound EXTTs in MTC show quantitative non-equivalence where there is more than one TL lexical item given for a

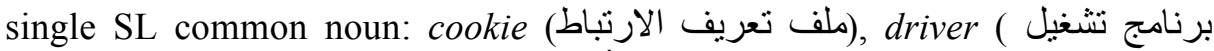

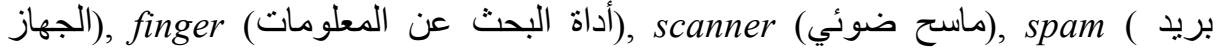
(عشوائي (م) etc. The compound EXTT in this type usually consists of a head noun followed by a modifier (an adjective, noun or noun phrase). Other compound EXTTs are based on quantitative equivalence between the SL and the TL. The SL compound in this type functions, syntactically and semantically, as one word regardless of its spelling (split, single-word or hyphenated), and the TL compound consists of a genitive construction where a head noun is used in a state of idäfah without the Arabic al-determiner prefix and followed by a

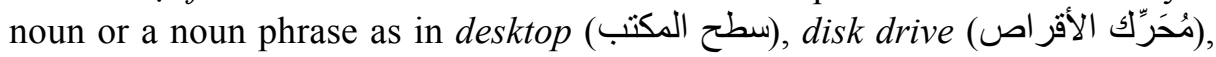
Enter key (هفتاح الإدخال), firewall (جدار حماية), password (كلمة المرور), user name (اسم المستخدم), etc. Though not common in traditional Arabic, compounding is extensively used in MSA especially for technical terms, "[w]ith the necessity for rapid translation of technical and computational terms from Western languages into Arabic, these kinds of lexical compounds have 
become more prevalent over the past two or three decades" (Ryding, 2005, p. $50)$.

\subsubsection{Acronyms and initialisms}

There are also SL technical compounds that are abbreviated as initialisms (i.e.

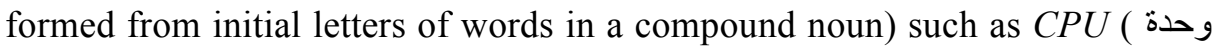
(المعالجة المركزية), DVD (قرص الفيديو الرقمي), FTP (برونوكول نقل الملفات), ISP aمُوَفر خدمة الإنترنت) and USB (الناقل النسلسلي العالمية) or as acronyms (initialisms pronounceable as a word) such as BIOS (نظام الإدخال/الإخراج الأساسي), LAN (شبكة اتصال محلية), RAM (ذاكرة وصول عشو ائي), WAN (شبكة اتصال واسعة), etc. In MTC, initialisms are given no translation but their compound nouns are given. This strategy suggests the inappropriateness of translating initialisms into TL equivalents which do not have the same referents of the SL term (e.g. $A L U$ ק.ح.9) (Mu jam Muștalaḥāt al-Hasibāt, 2012, p. 21) or Arabicising them without a TL explanation of the meaning of the term (e.g. BSC بي.إس.سي) (Mu 'jam Muștalahāat al-Hasibāt, 2012, p. 78). In this sense, Al-Qinai (2006) argues,

The somewhat high rate of illiteracy in the Arabic-speaking world may hamper the formation of native acronyms in view of the tendency among native speakers to make themselves comprehensible by avoiding opaque abbreviations. Since most advanced technology in the Arab world is imported from the west, the names and abbreviations are assigned by the countries of origin. (p. 49)

Like initialisms, acronyms in MTC are translated rather than Arabicised (e.g. RAM ذاكرة وصول عشوائي). However, in Mu 'jam Muștalahāt al-Hasibāt, acronyms are Arabicised with an explanation of the meaning of the term (2012, p. 437). Sometimes inaccurate transliteration of SL acronyms like BASIC (بيزيك) (بايوز) (Mu'jam Muștalahāat al-Hasibāt, 2012, p. 53) results in phonemic substitution of the sound $/ \mathrm{s} /$ in these words with $/ \mathrm{z} /$ in the TL words. Since there are no equivalent TL acronyms for SL technical acronyms, the only choices left for the translator are either to render the SL acronym as an EXTT or as an ATT followed by its TL explanation. According to Newmark (1988), "[a]cronyms are frequently created within special topics and designate products, appliances and processes, depending on their degree of importance; in translation, there is either a standard equivalent term or, if it does not yet exist, a descriptive term. Acronyms for institutions and names of companies are usually transferred" (p. 148). Therefore, SL acronyms that are used as proper names and those that have already found their way into the TL (usually written in lower case) are treated as ATTs "requiring analysis only for a less educated TL readership" (Newmark, 1988, p. 148).

\subsubsection{Blending}

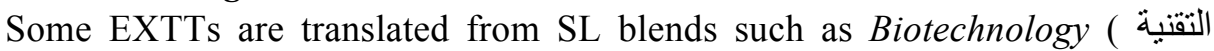
(كهرومغناطيسي) and e-mail (بيولوجية) electromagnetic (بيد إليكتروني) (often written email without a hyphen), emoticon (رموز المشاعر), etc. Most of these examples are rendered as TL compounds with the exception of electromagnetic (كهرومغناطيسي), which suggests that a TL blend is possible, not mandatory, if the clipped part in the SL blend is recoverable (e.g. electrofrom electricity). For example, SL blends like antivirus and monochrome 
cannot be translated as TL blends because the prefixes in both words, antiand mono-, are not recoverable. Yet, is it not possible to translate Biotechnology as (بيوتقنية) and e-mail as (إلكتروبريد) since the clipped part in the SL blend is recoverable? Though possible, translating Biotechnology as a TL compound (التقنية/التقانة/التكنولوجيا الحيوية) is more popular than the TL blend (بيوتقنية). Also, translating e-mail as a TL blend (إلكتروبريد) may result in semantic change if the Arabic prefix (إلكترو) is interpreted electrical (as in electromagnetic) rather than electronic. Another problem in TL blends lies in word order.

According to Al-Qinai (2006), "Arabic's aversion of blending can best be illustrated by the common English blend 'smog' which is rendered by four words in Arabic ضباب مخلوط بذخان [literally: fog mixed with smoke] despite the presence of a newly coined but less popular blend ضبخان" (p. 50). However, in translating smog as (ضبخان), SL word order is reversed in the translation (smoky fog becomes (ضباب دخاني) before al-naht (i.e. the blending process) to avoid semantic change and to conform to Arabic where the head (a noun) is followed by its modifier (an adjective or a noun) and not vice versa. It becomes clear now that the use of compounding is preferred to blending in translating SL blends because it maintains the words, and its meaning is clearer. Even in translating the prefix $e$ - in e-mail as (إليكتروني), there is an overlap between two different meanings of the adjectives electronic, "operating through the use of many small electrical parts such as microchips and transistors" and "operating by means of a computer: involving a computer or a computer system" (Merriam-Webster's Online Dictionary, 2016). Therefore, translating e-mail, "a system for sending messages from one computer to another" (Merriam-Webster's Online Dictionary, 2016), as (بريد) (حاسوبي is more accurate than translating it as (بريد إليكتروني), unless the intended meaning is any means or system for transmitting messages electronically (e.g. text messaging). Besides, translating the hyponym smiley as (رموز المشاعر) just like its hypernym emoticon, rather than (رمز الابنسامة), is an example of generalisation, which should be avoided in technical translation, because the TL word has a wider meaning than the SL word. The word icon itself in MTC is sometimes translated as a TTT (رمز) and sometimes as an ATT (أيقونة).

\subsection{Arabicised technical terms (ATTs)}

ATTs are TL technical terms borrowed from the SL and written in the characters of the Arabic alphabet to overcome non-equivalence between Arabic and the SL. Almost all ATTs are open-class words and among the open classes, nouns are the most frequently borrowed class because most of borrowed words are the names of objects and materials that are not known in the borrowing language (Bynon, 1977, p. 231). ATTs can be classified according to the phonological and morphological changes that occur to the SL technical term. Phonologically, the transference of the technical term may or may not involve phonemic substitution, omission or addition. Morphologically, there are three types of ATTs: non-inflectional/nonderivational, inflectional/non-derivational, and inflectional/derivational. Table 3 lists some examples of ATTs in MTC. 
Table 3. Arabicised technical terms (ATTs) in MTC

\begin{tabular}{|c|c|}
\hline SL Technical Terms & MTC Arabic \\
\hline archive & أرشيف \\
\hline battery & بطارية \\
\hline byte & بايت \\
\hline cable & كبل ك \\
\hline camera & كامير ا \\
\hline catalog & كتالوج \\
\hline computer & كمبيوتر \\
\hline electronic & إلكتروني \\
\hline flash & فلاش \\
\hline gigabyte & غيغابايت \\
\hline Internet & الإنترنت \\
\hline intranet & إنتر انت \\
\hline Macintosh & ماكنتوش \\
\hline magnetic & مُمَغَنَط \\
\hline megabyte & ميغابايت \\
\hline microphone & ميكروفون \\
\hline modem & مودم \\
\hline mouse & ماوس \\
\hline Pascal & باسكال \\
\hline programmer & مُمبَرِمِج \\
\hline protocol & بروتوكول \\
\hline strategy & استر اتيجية \\
\hline video & فيديو \\
\hline virus & فيروس \\
\hline Web & ويب \\
\hline
\end{tabular}

\subsubsection{Phonological changes}

As is shown in Table 3, some ATTs in MTC, such as byte (بايت), cable (كبل)), camera (كامير ا), catalog (كتالوج), computer (كمبيونر), flash (فلان), (فلاش), Mackintosh (ماكنتوش), microphone (ميكروفون), modem (مودم), mouse (ماون), (كاون), Pascal (باسكال), protocol (بروتوكول), web (ويبك), represent complete phonemic transference. Table 3 also reveals that some ATTs involve phonemic substitution, i.e. replacing SL phonemes that do not exist in the TL with other TL phonemes produced in the same place of articulation. The words gigabyte (غيغابايت) and megabyte (ميغابايت) are examples of ATTs which involve phonemic substitution. In classical Arabic, the letter jīm (ج) is pronounced as the voiced alveo-palatal affricate $/ \mathrm{d} z /$. Thus, the voiced velar stop $/ \mathrm{g} /$ in gigabyte and megabyte is replaced with a voiced velar fricative $/ \mathrm{\gamma} /$ (ghayn $\dot{\varepsilon}$ )

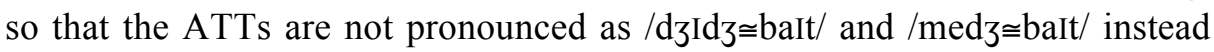

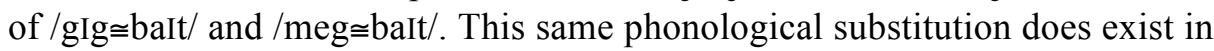
Arabicised words like Greeks (إغريق) and Gangrene (غرغرينا). However, in Egyptian Arabic, the letter jim (ج) is pronounced as the voiced velar stop /g/. 
Using /g/ only with ATTs will match the pronunciation of the SL term and facilitate back-translation.

Phonemic substitution in MTC also occurs in words like archive, video and virus in which the voiced labiodental fricative $/ \mathrm{v} /$ in the SL words is replaced with a voiceless labiodental fricative /f/ in the transliterated TL words due to the fact that Standard Arabic does not have a letter representing the sound /v/. If the Arabicised letter ( $)$ is not possible in word processing for technical restrictions, the letter $f \bar{a}^{\prime}(\omega)$ is often used instead. A third example of phonemic substitution is the replacement of the nonpharyngealised voiceless alveolar stop $/ \mathrm{t} /(t \bar{a}, ت)$ with a pharyngealised voiceless alveolar stop /t $\Re /(t a \bar{a}, b)$ in magnet (مَغْنَاطِيس). An example of phonemic omission is the omission of the final $/ \mathrm{k} /$ in adjectives like electronic and strategic (إلكتروني), where yā' al-nisbah (suffix of attribution) is added to the ATT. An example of phonemic addition is the addition of the sound /g/ to the translation of the word program (بَرْنامَنج). The word barnamaj (بَرْنامَج) itself is borrowed from the Persian word parnamah (بَرْنَنَامَهَ), which means (الورقة الجامعة للحساب، والخطة المرسومة لعمل مانجان (al-Mu'jam al-Wasìt, 2004, p. 52). Another example of phonemic addition is the addition of the sound /s/ in magnet (مَغْنَاطِيس).

\subsubsection{Morphological changes}

\subsubsection{Non-inflectional/non-derivational ATTs}

As is shown in Table 3, ATTs borrowed from SL proper names are solid stems in the sense that they cannot be analysed according to the TL derivational system of root-pattern or the TL inflectional system of gender, number, case and definiteness. These ATTs include names of programming languages (Java, Pascal, Perl, Visual Basic, etc.), websites (Amazon, YouTube, Google, Facebook, Yahoo, etc.), operating systems (Windows, Mac, Linux, etc.), hardware brands (Asus, Dell, Toshiba, Lenovo, etc.), software brands (Adobe, McAfee, Microsoft Office, Photoshop, Firefox, etc.), standard measurement units, commonly abbreviated (megabyte, megapixel, gigabyte, Hertz, terabyte, etc.). The translation of such proper names, however, should be based on Newmark's (1988) recommendation that "[w]here an SL technical term has no known TL equivalent, a descriptive term should be used" (p. 154). Accordingly, some descriptive terms should precede such terms as in

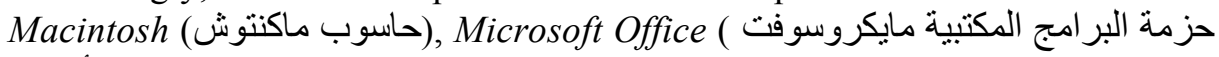
(أوفيس), and Pascal (لغة برمجة باسكال) at least in the first time the technical term is used in the TL text.

Moreover, proper nouns in Arabic are known by convention and through the fact that they have the grammatical property of being definite even though they do not carry the Arabic al- determiner prefix. Typically, English proper names are not preceded by an article (the or a/an) or other determiners. Therefore, expressions such as Microsofts, the Microsoft and another Microsoft are not Standard English. The word Internet (الإنترنت), capitalised, is used in MTC as a proper noun to refer to "the worldwide connection of computers on which we can find the World Wide Web" (Paxson, 2004, p. 3), whereas the word internet as a common noun refers to "any collection of networked computers" (Paxson, 2004, p. 3). MTC preferred the ATT (إنترنت) to the TTT (الثبكة الدولية للمعلومات) so as not to be confused with $W W W$ as one of Internet services if the prefix inter- is interpreted as international (network) 
rather than between (network). The Arabic al- determiner prefix in this case is lām ză'idah ghayr läzimah (an unnecessary al- determiner prefix). Though an SL proper noun, the word Internet is used as an adjective in Mu'jam Muștalahạt al-Hasibāt in the translation of netiquette as (أخلاقيات إنترنتية) and netizen as (مواطن إنترنتي) (Mu ‘jam Muștalahạt al-Hasibāt, 2012, p. 377). Similarly, the capitalised word Web (ويب) is a proper noun that refers to World Wide Web as "a part of the Internet accessed through a graphical user interface and containing documents often connected by hyperlinks" (MerriamWebster's Online Dictionary, 2016).

It should be noted that some technical verbs like to google or to xerox, which are converted from the proper nouns Google and Xerox respectively, are sometimes translated into the TL with no reference to the SL proper noun. In this sense, the verb google (translated as يبحث على شبكة الإنترنت) refers to using any web search engine, and the verb xerox (translated as بطبع) refers to using any printer. However, if the converted verb is capitalised in the SL text, then the SL proper noun should be Arabicised in the TL text. In this sense the capitalised verb Google (يبحث بواسطة محرك البحث جوجل) means using the Google search engine to obtain information on the Web, and the verb Xerox means using a Xerox machine to print.

\subsubsection{Inflectional/non-derivational ATTs}

The second type of ATTs "includes borrowed words which cannot be integrated completely because of their incompatibility with the structure of the Arabic language" (Mahadin, 1996, p. 327). These are borrowed SL terms derived from common linguistic roots that assimilate, with varying degrees, to the TL inflectional system of gender (masculine and feminine), number (singular, dual and plural), case (nominative, genitive and accusative) and definiteness (the definite al- prefix and the indefinite suffixes of altanwin/nunation). Examples of this type include technical terms such as cable (كبل), computer (كمبيوتر), flash (فيكروفون), microphone (ملاش), modem (مودم), mouse (ماوس), virus (قيروستروس), etc. Yet, for many of these partially-naturalised ATTs, there are acceptable Arabic equivalents that can be used instead to preserve the integrity and authenticity of the language. Unlike strategy, which is Arabicised as (استر اتيجية), the word technology, for example, is translated in MTC as (تقنية) rather than Arabicised (تكنولوجيا), which draws attention to the possibility of using TTTs even for naturalised ATTs. For the word cable it is possible to use the Arabic word (سلكيط من المعدن دقيق (و) (س) (أو غليظ كسللك الكهرباء ونحوه (a] thin or thick rope of metal that carries electricity" (al-Mu jam al-Wasìt, 2004, p. 445). The word computer, as stated earlier, can be translated as hasūb (حاسوب) which is ism al-'àlah (noun of instrument) derived from the Arabic root hasaba (حسب), a TL equivalent for the English verb compute "to find out (something) by using mathematical processes" (Merriam-Webster's Online Dictionary, 2016). So, if the derived TL hasūb (حاسوب) is a misnomer because a computer does more than mathematics, so is the SL term itself. In this context, the Arabic translation (حاسب آلي), derived from ism al-fā 'il (active participle), is inaccurate because a computer cannot work without being told what to do. Both (حاسب) and (حاسوب), however, are used interchangeably in Mu'jam Muștalahāt al-Hasibāt (2012, p. 18). A word like microphone, for example, has its Arabic EXTT (مِجهار) (al-Mu'jam al-Wasitt, 2004, p. 143). The problem with the Arabic 
equivalent is that it lacks popularity although it shows precision (of meaning), brevity (of wording) and integrity (in morphology).

The word mouse, used in English due to the resemblance between the device and the animal, is transliterated in MTC rather than translated into the Arabic ( $f a^{\prime} r a h$ فأرة), although a number of languages, including Arabic, have substituted for the SL word mouse, their own native words (e.g. German maus, French souris, etc.). To avoid semantic ambiguity in the TL, the word is usually followed by a descriptive term (فأرة الكمبيوتر). The Arabic word (فأرة) has been extended semantically to encompass the meaning of the SL word plane (أداة للنجار يقشر بها الخشب (محدثة) (al-Mu 'jam al-Wasìt, 2004, p. 670) although the English word has a less popular Arabic equivalent (مسنْحَج ). The existence of TTT and EXTT versions of plane indicates the possibility of having an EXTT version for mouse along with its TTT (أرة الحاسوب أو (أو (المُوَشَّرة defined as "[a]n input device used to control an on-screen cursor for such actions as 'pressing' on-screen buttons in dialog boxes, choosing menu items, and selecting ranges of cells in spreadsheets or groups of words in a document" (MTC, 2016). In Mu 'jam Muștalahāt al-Hasibāt, both mouse and

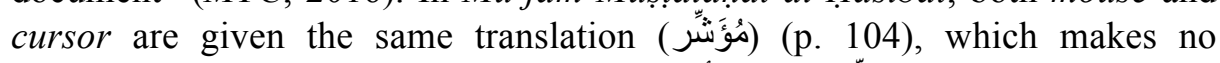

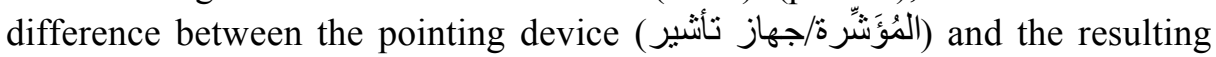
mark on the screen (إنشارة).

The ATTs of words like computer (كمبيوتر), microphone (ميكروفون), modem (مودم), mouse (ماوس), though more popular in spoken Arabic than their TTTs, are problematic in written Arabic in situations of al-tașriff (morphological affixation) because "[t]he difference between the word formation processes in Arabic and the donor languages (mostly IndoEuropean) is great, which is supposed to make the process of adaptation face many structural difficulties, especially in morphology borrowed words must be used like any other words in the recipient language, i.e. Arabic" (Mahadin, 1996, p. 330). In other words, partially-naturalised ATTs are not productive for other derivations, "[t]hese accept only the addition of inflectional morphemes, usually the regular plural marker" (Mahadin, 1996, p. 336). The same strategy is used in words such as computers (كمبرات) (كبيوترات) and batteries (بطاريات), cables (كابلات), microphones (ميكروفونات) which are transliterated into the TL and remodelled to conform to Arabic word patterns of forming the sound feminine plural (جمع المؤنَّث السالم) Jam 'al-mu'annath al-sālim in which the plural noun ends with the suffix - $\bar{a} t(ا)$ ). Some ATTs that show a high level of inflectionability, though still not derivational, have been approved as Arabic words by the Academy of the Arabic Language in Cairo: such as battery (بطارية) (al-Mu jam al-Wasit t, 2004, p. 61) which accepts inflectional markers of al-jam ' (بطابطاريات), al-tathniyah (dual) (بطاريتين), al-ta'nìth (femininity) (بطارية), al-tanwin (nunation) (بطاريبة), al-milkiyah (possession) (بطاريته) (الإلكترون) (al-Mu jam al-Wasit t, 2004, p. 24) which accepts less inflections.

\subsubsection{Inflectional/derivational ATTs}

The third type of ATTs "includes words which can assimilate completely and become productive for other derivations" (Mahadin, 1996, p. 327). ATTs of this type are inflectional as well as analysable into judhür (roots of three or four consonants) and 'awzān (patterns of vowels and consonants). For example, the verb yubarmij (to program يَيَرْمِج) is productive for other Translation \& Interpreting Vol 9 No 2 (2017) 


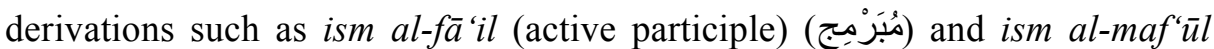
(passive participle) (مَبَرَمْنج), and maṣdar (verbal noun) (بَرْمَجَ). Similarly, the verb yumaghnit (to magnetise (يََنَّن), abstracted from the noun magnet

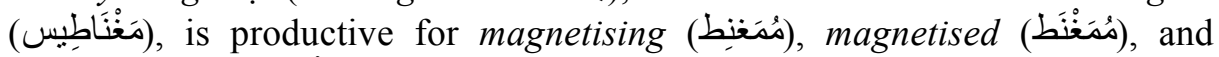
magnetism (مَفْنَاطِيسية). A third example is the verb yu'arshif (to archive

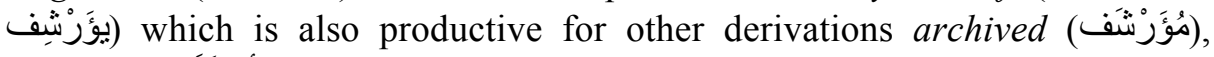
archiving (أرََْْفَفَ), etc. In translation, it would be rather difficult to replace a fully-naturalised ATT with a TTT or an EXTT unless an extensive effort is done by the technical translator to avoid any loss of meaning that accompanies the transference of the technical term.

\section{Conclusions}

Based on the analysis of some examples of technical terms in the Microsoft Terminology Collection (MTC) (English-Arabic), the following statements could be given as "guidelines", rather than "rules", for English-Arabic technical translators:

1. In their English-Arabic translations, comprehensive multilingual resources of technical terminology, such as Microsoft Terminology Collection (MTC) and the like, as well as English-Arabic dictionaries of computer terms, should follow a clearly-stated translation policy whether in using a standard TL translation for the standard SL term in the same translation situation or in using the same translation strategy for similar SL terms, instead of using methods of translation, Arabicisation, and Arabic-expanding techniques inconsistently (i.e. using more than one strategy for a standard SL term in the same translation situation or using different translation strategies for similar technical terms).

2. Uniformity in technical translation (i.e. using particular TL terms for standard SL technical terms) would give the TL term the same meaning, depth and applications of the SL term and encourage standardisation and unification of technical terminology in the TL culture.

3. Due to the ability of the Arabic language to cope with the dramatic increase in English technical terms by means of derivation, compounding and semantic extension, it is more appropriate to use translation (mainly semantic extension) and Arabic-expanding techniques (mainly derivation and compounding) rather than Arabicisation (i.e. lexical-semantic transference) to provide TL equivalents for SL technical terms derived from common linguistic roots as long as the term denotes either the whole class or any random member of the class.

4. Arabicisation (i.e. transliteration) should only be used with SL technical terms used as proper nouns such as names of programming languages, websites, operating systems, hardware brands, software brands, and standard measurement units (with an identifying TL descriptive term and without the Arabic al-determiner prefix).

5. It is possible to translate SL proper names of accessories or essential applications that are included within all versions of Microsoft Windows and brand names of electronic devices both as EXTTs and 
ATTs to differentiate between the common use of the word and the trademark.

6. Using informal ATTs is not acceptable in the translation of technical documents that are very formal or scientific. The fact that some TL technical terms are common in their informal Arabicised forms among specialists and non-specialists who find these forms appropriate for the daily use, draws attention to the necessity of using the TL technical term within its proper sphere depending on its level of formality.

7. Since there are no equivalent TL acronyms for SL technical acronyms, the only choices left for the translator are either to render the SL acronym as an EXTT or as an ATT depending on the length or complexity of the SL technical term as well as its popularity in the TL culture. Translating SL technical initialisms into TL equivalents which do not have the same referents of the SL term or Arabicising them should be avoided in technical translation. A translation of the original compound noun should be given instead.

8. The use of compounding is preferred to blending in translating SL technical blends because it maintains the full words, and thus results in clearer meanings.

9. As a result of phonological differences between the SL and the TL, translating SL technical terms as ATTs sometimes involves phonological changes such as phonemic substitution, omission and addition.

10. ATTs borrowed from SL proper names cannot be analysed according to the TL derivational system of root-pattern or the TL inflectional system of gender, number, case and definiteness.

11. Borrowed SL technical terms derived from common linguistic roots can assimilate, with varying degrees, to the TL inflectional and derivational systems.

12. For many inflectional/non-derivational ATTs in MTC, there are acceptable Arabic equivalents that can be used instead in formal technical translation situations.

13. Any attempt to replace an ATT (partially or fully naturalised) with a TTT or an EXTT in existing technical translations should be the result of an extensive effort made by the English-Arabic technical translator to avoid any loss of meaning that accompanies the transference of the technical term.

14. The Arabic-speaking world is the main audience for English-Arabic technical translation, and in this sense, technical translators, experts, academics and educational institutions in the field of information technology (IT) should be encouraged to use TTTs or EXTTs for new technical terms derived from common linguistic roots to preserve the integrity and authenticity of the Arabic language. Whether new technical terms should be rendered as TTTs or EXTTs depends on aspects of precision, brevity and integrity.

\section{References}

Abu Hatab, W., \& Lahlali, M. (2014). Advanced English-Arabic translation: A practical guide. Edinburgh: Edinburgh University Press. 
Al-Abed Al-Haq, F. (1998). Toward a theoretical framework for the study of planning Arabicization. In A. Shunnaq, C. Dollerup \& M. Saraireh (Eds.), Issues in translation (pp. 53-68). Irbid National University \& Jordanian Translators' Association.

Al-Asal, M. S., \& Smadi, O. M. (2012). Arabicization and Arabic expanding techniques used in science lectures in two Arab universities. Asian Perspectives in the Arts and Humanities, 2(1), 15-38.

Al-Qinai, J. (2000). Morphophonemics of loanwords in Arabic. Studies in the Linguistic Sciences, 30(2), 1-25.

Al-Qinai, J. (2006). Code-switching and style shift in translation. In C. M. Figueroa \& T. M. Gárate (Eds.), Studies in contrastive linguistics: Proceedings of the 4th international contrastive linguistics conference, Santiago de Compostela, September 2005 (pp. 45-58). Santiago de Compostela: University of Santiago de Compostela.

al-Mu'jam al-Wasit . (2004). Cairo: The Academy of the Arabic Language.

Baker, M. (1987). Review of methods used for coining new terms in Arabic. META, 32(2), 186-188.

Benabdi, L. (1980). Arabicization in Algeria: Processes and problems (PhD thesis). Indiana University, Bloomington.

Bernstein, T. (1995). The careful writer. New York: Simon and Schuster.

Bynon, T. (1977). Historical linguistics. Cambridge: Cambridge University Press.

Byrne, J. (2006). Technical translation: Usability strategies for translating technical documentation. Dordrecht: Springer.

Chejne, A. (1969). The Arabic language: Its role in history. Minneapolis: University of Minnesota Press.

Dirven, R., \& Verspoor, M. (2004). Cognitive exploration of language and linguistics. Amsterdam/Philadelphia: John Benjamins.

Ghazala, H. (1995). Translation as problems and solutions: A course-book for university students and trainee translators. Valetta, Malta: Elga.

Hartford, B., \& Obeng, S. G. (2002). Political independence with linguistic servitude: The politics about languages in the developing world. New York: Nova Science.

Husni, R., \& Newman, D. L. (2015). Arabic-English-Arabic-English translation: Issues and strategies. New York: Routledge.

Mahadin, R. S. (1996). Patterns of reinterpretation of word formation of Arabized words. Language Research, 32(2), 327-349.

Merriam-Webster's Online Dictionary. (2016). Retrieved from http://www.merriamwebster.com/dictionary

Microsoft Language Portal. (2016). Retrieved Jan. 20, 2016, from https://www. microsoft.com/Language/en-US/Default.aspx

Mu 'jam Muștalahāt al-Hasibāt. (2012). Cairo: The Academy of the Arabic Language.

Newmark, P. (1988). Approaches to translation. Hertfordshire: Prentice Hall.

Numan, A. (1981). Arabicization: Theory and practice in Arabic. Algeria: The National Company for Publication and Distribution.

Olohan, M. (2015). Scientific and technical translation. New York: Routledge.

Paxson, P. (2004). Media literacy: Thinking critically about the Internet. Maine: Walch.

Ryding, K. C. (2005). A reference grammar of Modern Standard Arabic. Cambridge: Cambridge University Press.

Schubert, K. (2010). Technical translation. Amsterdam/Philadelphia: John Benjamins.

Stetkevych, J. (1970). The modern Arabic literary language. Chicago: The University of Chicago Press.

Stockwell, R., \& Minkova, D. (2001). English words: History and structure. Cambridge: Cambridge University Press.

Versteegh, K. (2014). The Arabic language. Edinburgh: Edinburgh University Press.

Wright, S. E., \&Wright, L. D. (1993). Scientific and technical translation. Amsterdam/Philadelphia: John Benjamins. 